\title{
Globalization and structural adjustment as a development tool
}

\author{
Working Paper No. 31
}

Frédéric Lapeyre

Policy Integration Department

World Commission on the Social Dimension of Globalization

International Labour Office

Geneva

July 2004 
Copyright $($ International Labour Organization 2004

Publications of the International Labour Office enjoy copyright under Protocol 2 of the Universal Copyright Convention. Nevertheless, short excerpts from them may be reproduced without authorization, on condition that the source is indicated. For rights of reproduction or translation, application should be made to the Publications Bureau (Rights and Permissions), International Labour Office, CH-1211 Geneva 22, Switzerland. The International Labour Office welcomes such applications.

Libraries, institutions and other users registered in the United Kingdom with the Copyright Licensing Agency, 90 Tottenham Court Road, London W1T 4LP [Fax: (+44) (0)20 7631 5500; email: cla@cla.co.uk], in the United States with the Copyright Clearance Center, 222 Rosewood Drive, Danvers, MA 01923 [Fax: (+1) (978) 750 4470; email: info@copyright.com] or in other countries with associated Reproduction Rights Organizations, may make photocopies in accordance with the licences issued to them for this purpose.

ISBN 92-2-116314-8 (printed version)

92-2-116315-6 (web version)

First published 2004

Cover:

The designations employed in ILO publications, which are in conformity with United Nations practice, and the presentation of material therein do not imply the expression of any opinion whatsoever on the part of the International Labour Office concerning the legal status of any country, area or territory or of its authorities, or concerning the delimitation of its frontiers.

The responsibility for opinions expressed in signed articles, studies and other contributions rests solely with their authors, and publication does not constitute an endorsement by the International Labour Office of the opinions expressed in them.

Reference to names of firms and commercial products and processes does not imply their endorsement by the International Labour Office, and any failure to mention a particular firm, commercial product or process is not a sign of disapproval.

ILO publications can be obtained through major booksellers or ILO local offices in many countries, or direct from ILO Publications, International Labour Office, CH-1211 Geneva 22, Switzerland. Catalogues or lists of new publications are available free of charge from the above address, or by email: pubvente@ilo.org

Visit our website: www.ilo.org/publns

Printed by the International Labour Office, Geneva, Switzerland 


\section{Globalization and structural adjustment as a development tool}

\section{Contents}

Foreword iii

Preface $\mathrm{V}$

1. Introduction ........................................................................................................ 1

2. The neo-liberal counter-revolution and its policy implications ..................................... 3

3. From the structural adjustment doctrine to the Washington Consensus .................... 6

4. The poor results of structural adjustment programmes ..............................................8 8

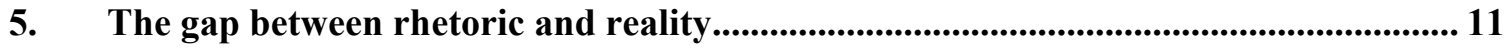

6. Towards a new generation of structural adjustment policies .................................. 14

7. Social conflicts and development: Some lessons for policy-making ............................. 18

8. From goals to reality: The long march of domestic and global reforms ..................... 20

8.1 The Millennium Development Goals and structural adjustment .................. 20

8.2 Globalization must work for all: The need for global governance

8.3 Towards human development oriented structural adjustment policies

9. Conclusion 25 


\title{
Foreword
}

In February 2002, the ILO established an independent World Commission on the Social Dimension of Globalization, co-chaired by President Tarja Halonen of Finland and President Benjamin Mkapa of Tanzania and comprising 26 eminent commissioners from a wide range of walks of life and different parts of the world, each serving in their individual capacity. Its broad goals were to: identify policies for globalization that reduce poverty, foster growth and development in open economies, and widen opportunities for decent work; to explore ways to make globalization inclusive, so that the process can be seen to be fair for all, both between and within countries; to promote a more focused international dialogue on the social dimension of globalization; to build consensus among key actors and stakeholders on appropriate policy responses; and to assist the international community forge greater policy coherence in order to advance both economic and social goals in the global economy.

The report of the World Commission, A fair globalization: Creating opportunities for all, was released on 24 February 2004. It is available on the Commission's website www.ilo.org/public/english/wcsdg/index.htm.

A secretariat was established by the ILO to support the Commission. Among other tasks, it compiled information and commissioned papers on different aspects of the social dimension of globalization. The aim was to provide the Commission with documentation and data on a wide range of options and opinions concerning subjects within its mandate, without committing the Commission or individual Commissioners to any particular position on the issues or policies concerned.

Material from this background work is being made available as working papers, as national and regional reports on meetings and dialogues, and in other forms. Responsibility for the content of these papers and publications rests fully with their authors and their publication does not constitute an endorsement by the World Commission or the ILO of the opinions expressed in them.

\author{
Gerry Rodgers \\ Director \\ Policy Integration Department
}




\title{
Preface
}

The Technical Secretariat to support the World Commission on the Social Dimension of Globalization first prepared a synthesis of ILO activities on the Social Dimension of Globalization (published as Working Paper No. 1 in this series). Documentation on the work and outcomes of other major commissions, an ideas bank, a database and knowledge networks of experts and social actors were subsequently developed. These networks have dealt with several topics, including: inclusion at the national level for the benefits of globalization to reach more people; local markets and policies; cross-border networks of production to promote decent work, growth and development; international migration as part of the Global Policy Agenda; international governance (including trade and finance); the relationship between culture and globalization; and values and goals in globalization. Gender and employment aspects were addressed throughout this work. The Reports on the Secretariat's Knowledge Network Meetings are available on the Commission's web site or in a special publication from the ILO (ISBN 92-2-115711-1).

During the course of these activities, a number of substantive background papers were prepared, which are now made available for wider circulation in the Policy Integration Department's Working Paper series (Nos. 16 to 38), as well as on the Commission's website.

The present paper, prepared by Professor Frédéric Lapeyre of the Institute d'Etudes de Développement, Université Catholique de Louvain, argues that economic globalization has become a key feature of the life of economic and social actors around the world, but that this is not tantamount to political inertia and requires on the contrary a rethinking of development policies and new forms of action. Prof. Lapeyre reviews in that respect past structural adjustment policies which were for many countries an important element of their economic liberalization policies, and argues that these adjustment policies must substantially change, if they were to reach their objective of reducing poverty and a better integration in a globalizing world.

\author{
Rolph van der Hoeven \\ Manager, Technical Secretariat \\ World Commission on the Social Dimension of Globalization
}

July 2004 




\section{Globalization and structural adjustment as a development tool ${ }^{1}$}

\section{Introduction}

The development debate has focused for more than a decade now on the social and economic costs and benefits of global integration and on how to make globalization work for all. A broad consensus has emerged regarding globalization as characterized by a process of time and space compression resulting from technological innovation (in particular, in the sector of information and communication technologies) leading to the emergence of a global world, shared in a process of hybridization and interconnection. Day-to-day activities are increasingly influenced by events happening on the other side of the globe, while the practices and decisions of local groups can have significant global reverberations. $^{2}$

In such a context, the debate between pro and no global is misleading as it obfuscates the main policy issues. Whether we like it or not, economic globalization has become a key feature of the life of social and economic actors all around the world. We must accept this with a sense of realism, otherwise our actions will lack effective impact. However, this is not tantamount to political inertia, but it means rethinking development policies and forms of action on the international and domestic scene in an entirely new way.

Once we have acknowledged that globalization is a fact, it is crucial to re-open the debate on the paths of sustainable integration. Far from the one-path model of the Washington Consensus, structural adjustment programmes should reflect the diversity of socio-economic contexts and the specific conditions and needs for a pro-poor and pro-social justice integration of the countries of the world, especially the poorest, into the global economy. It is fundamentally important to be clear on the means and ends in the global era.

\footnotetext{
${ }^{1}$ This paper has benefited from the mass of information collected within the UN Intellectual History Project (see the first volume of the UN Intellectual History Project Series for additional information: Louis Emmerij, Richard Jolly, and Thomas G. Weiss, 2001, Ahead of the Curve? UN Ideas and Global Challenges. (Bloomington: Indiana University Press. Many of the issues raised in this paper will be developed in a new volume of the UNIHP series: R. Jolly, L. Emmerij, D. Ghai, F. Lapeyre. Forthcoming. The UN contributions to development thinking and practices, Bloomington, Indiana University Press.

${ }^{2}$ Held, D. 1995. Democracy and the global order. Cambridge, Polity Press, p. 20.
} 
The current imperatives are sustainable human development and the fight against poverty and inequalities. This requires, on the one hand, appropriate policies at national and local level for an optimal use of globalization from a sustainable development perspective; and, on the other hand, effective global governance that would promote global human development and give developing countries the opportunity to improve their living and working conditions. ${ }^{3}$

The past 20 years have demonstrated the critical role of politics in economic policy and structural transformation. Confusion regarding globalization is emanating from the highly ideological equation of this notion - as defined above - with the "holy trinity" of any neo-liberal programme: liberalization, deregulation and privatization. But they are two distinct processes. The former largely depends on technological changes, whereas the latter is a matter of conscious policy choice that will determine the degree of openness of the national economy and its vulnerability to external forces with regard to human development objectives; they are not merely fashionable ideas without any consequences. As Hurst argues:

Yet under the rhetoric of responding to international competitive pressures many countries are cutting welfare, attempting to reduce wages, and rendering labours markets more competitive. They are in danger of damaging prosperity by undermining its social foundation. ${ }^{4}$

The real issues relate to the political economy of globalization.

This paper will focus on the evolution of thinking on structural adjustment over the past 20 years. It highlights the pro-liberalization ideological bias of both the first generation of structural adjustment programmes, designed by the Bretton Woods institutions, and subsequently the Washington Consensus. In the late 1990s, poor growth performance, growing social problems, and sustainability issues led to the emergence of a new generation of pro-poor oriented structural adjustment policies. This paper will assess the merits and limitations of the new comprehensive development framework of the post-Washington Consensus era - and especially issues relating to the Poverty Reduction Strategy Papers. In its conclusion, the paper turns to the future: what lessons can we draw from the record of past structural adjustment policies that can help improve their contribution to sustainable development in the years ahead?

\footnotetext{
${ }^{3}$ Helleiner, G. 2001. "Markets, Politics and Globalization: can the global economy be civilised?", in Journal of Human Development, Vol. 2, No.1, p. 44.

${ }^{4}$ Hirst, P. "The global economy - myths and realities", in International Affairs, Vol. 73, No. 3, pp. 424-425.
} 


\section{The neo-liberal counter-revolution and its policy implications}

The 1980s will be remembered for four noteworthy changes. This decade witnessed a neo-liberal counter-revolution in both the academic and political spheres. It marked a decisive turning point in development policies pursued hitherto by most developing countries. It also constituted a watershed in the role played by the United Nations (UN) system in generating ideas and influencing strategies for development. Fourthly, this decade saw a serious erosion of the power of developing countries in shaping their domestic economic policies, and an increasing role of the Bretton Woods institutions in influencing development policies through conditionality mechanisms.

The neo-liberal counter-revolution that occurred in the academic world in the late 1970s, eulogizing the virtues of free markets and private enterprise and the evils of state intervention, fell on the receptive ears of the new conservative leaders who came to power in the United Kingdom and the United States, Margaret Thatcher and Ronald Reagan. The diagnostic was clear in the new mainstream paradigm: government intervention in the economy was the primary cause of disturbance; and the best way to control the level of economic activity was through monetary policy. Inflation was essentially a monetary phenomenon, and could be brought under control through a restrictive monetary policy. The essence of the "new" thinking was that the objectives of poverty reduction and growth are best served by reliance on market forces and private enterprise and restriction of the role of the State to a minimum of essential functions. ${ }^{5}$

The neo-liberal counter-revolution targeted the conception of civil servants and governmental decision-making bodies as disinterested Benthamite social guardians. ${ }^{6}$ It stressed the welfare cost of state failures and the irrational allocation of resources resulting from public interventionism. The public choice and rent-seeking research programmes aimed at integrating economic and politics issues by introducing the notion of "self-interest". According to this perspective, the government was no longer an exogenous force, trying to do well, but was at least partially endogenous, and the policies it instituted reflected vested interests in society. ${ }^{7}$ The new political economy emphasized, on the one hand, that market failures were less damaging than state failures; and, on the other, that any interference by the "predatory State" with the "magic of the marketplace" was bound to make matters worse. Indeed, even if a government policy clearly identified its

${ }^{5}$ B. Balassa. 1968. Economic Growth, Trade and Balance of Payments in Developing Countries 1960-65. Washington, D.C., World Bank; I. Little, T. Scitovsky, M. Scott. 1970. Industry and Trade in Some Developing Countries, London, Oxford University Press; J. Bhagwati and A. Krueger. 1978. Foreign Trade Regimes and Economic Development: Liberalization Attempts and Consequences. Cambridge: Ballinger; D. Lal. 1994. Against Dirigism. San Francisco, ICS Press.

${ }^{6}$ Krueger, A. 1990. "Economists' changing perceptions of government", in Weltwirstschaftliches Archiv, Band 126, Heft 3, p. 428.

${ }^{7}$ Colander, D. 1984. Neo-classical Political Economy, Cambridge, Ballinger, p. 2. 
beneficiaries and/or victims, those groups would tend to organize in support or opposition to the policies, then lobby to increase the value of the gains, or reduce the value of losses, ensuing from those policies. Thus despite the relevance of the initial objectives of state interventionism, its perverse effects were such that its intervention is most often counter-productive, and worsens the situation rather than improve it.

In this context, the policy recommended state withdrawal from the economic sphere and the promotion of market mechanisms as the main engine of growth and development. The call "to get one's own house in order", coming from the new political economy, opened a phase of minimal state intervention and external and internal liberalization, which had a huge impact on the developing countries and the well-being of their populations in the 1980s. The widespread acceptance of this orthodoxy in the 1980s was not based on any empirical evidence of its effectiveness, but rather on a violent reaction against the previous Keynesian and social democratic orthodoxies that held sway during the period of vigorous world economic growth that stretched from the end of the Second World War to the stagflationary era of the mid-1970s. ${ }^{8}$

In the area of international trade analysis, the late 1970s and the beginning of the 1980s were marked by the rejection of past import-substitution strategies and the state interventionism associated with it. The research and literature on the cost of rent seeking, which became one of the few leading topics of research, evolved the key idea that an export-oriented development policy could have favourable effects on growth performance and well-being. This was the result of such traditionally cited factors as economies of scale or the stimulating effects of foreign competition, and the fact that such a policy limits the use of quantitative restrictions, and the distortions of economic incentives that accompany them. ${ }^{9}$

In this context, the central objective of macroeconomic policy became the control of inflation through monetary policy, devaluation and the attainment of budgetary balances. Led by Thatcher and Reagan, the policy side of the "counter-revolution" resulted in curbs on trade unions, reduction in taxes and welfare expenditure, the privatization of state enterprises, reduction or abolition of subsidies and price controls, deregulation of key sectors of the economy, and liberalization of exchange restrictions. The solution to the crisis, in the North as in the South, was to allow the market to determine how economic resources can more productively be allocated, and to rely on market forces as the principal determinant of economic decision.

This neo-liberal counter-revolution and the newly elected governments in the North had a profound impact on the operations of the International Monetary Fund (IMF) and the World Bank. As an agency concerned primarily with financial stability in an open and market-oriented economic system, the IMF had a traditional bias in favour of macroeconomic balance, control of inflation and trade and financial liberalization. The new doctrine reinforced these proclivities.

${ }^{8}$ Epstein, G., H. Gintis. 1995. "Economic policies for sustainable growth" in G. Epstein and H. Gintis, eds., Macroeconomic policy after the conservative era. Cambridge, Cambridge University Press.

${ }^{9}$ Lipsey, R. 1978. Foreword for Bhagwati and Krueger, op. cit., p. xv-xvi. 
One cannot understand the role played by the Bretton Woods institutions in the 1980s without taking into account the debt crisis that affected most of the developing countries in the early 1980s. ${ }^{10}$ While the burden of external debt was a topic of discussions on international development since at least the 1960 s, it became a major global preoccupation in the early 1980s. Debt service as a proportion of exports of goods and services for developing countries rose from less than 9 per cent in 1975 to around 11-12 per cent after 1980. The regional differences are quite considerable: for Latin America, the ratio rose sharply from 20 in 1975 to nearly 40 per cent in 1982, but fell later to 22 in 1995; the debt service ratio rose sharply for sub-Saharan Africa from less than 7 per cent in 1975 to around 19 per cent in the 1990s. ${ }^{11}$

After the debt crisis, developing countries were forced to turn to multilateral financial institutions for loans. Increasingly these institutions and bilateral donors and private banks insisted upon the adoption of policies of stabilization and liberalization as conditions for new loans and debt rescheduling. Baker's plan emphasized those countries which are not ready to undertake basic adjustments, in cooperation with international financial institutions, could not expect to benefit from the programme. Efforts by any country "“"to go it alone" are likely seriously damage its prospects for future growth". ${ }^{12}$ The rescheduling mechanisms, agreed by the main donors and the international financial system, led to the almost total loss of autonomy of developing countries in the definition of their development policy priorities. This power was transferred to the IMF and the World Bank, which put a high conditionality on the access to their resources, and pushed developing countries towards structural adjustment programmes. Thus, in the 1980s most developing countries had initiated programmes of economic liberalization and adjustment under the tutelage of the Bretton Woods institutions.

Some developing countries, due to mismanagement of their economies, had also run into intractable problems of persistent inflation at galloping rates, and structural adjustment clearly had to take place. A few suffered from stagnation and an extreme distortion of their economies caused by a breakdown in market mechanisms and the pervasive role of the state sector in the ownership and management of their economy. These indebted countries had no choice but to pursue this orthodox set of policies that were designed in a universal way to correct financial and payment imbalances, under IMF supervision. Initially the policies were mainly macroeconomic stabilization policies, and amounted to the reduction of public expenditure, increase in revenue, devaluation, and the removal of price controls. Later, they evolved into a broader package, involving trade liberalization and foreign exchange restrictions, deregulation of the economy, privatization, and the other elements of what came to be called the "Washington Consensus", reviewed below.

10 The Pearson Commission on International Development Reporting in 1970 devoted an entire chapter to the debt problem. See Partners in Development. New York, Praeger.

${ }^{11}$ Jolly R., L. Emmerij, D. Ghai, F. Lapeyre. Op. cit., p. 145.

${ }^{12}$ Baker III, J. 1986. “Endettement et changement structurel”, in Travail et Société, No. 3. 


\section{From the structural adjustment doctrine to the Washington Consensus}

The expression "Washington Consensus" came to stand for the stabilization, liberalization and structural adjustment policies, advocated by the Bretton Woods institutions and the major industrial countries. The various components of this policy package were summarized well by John Williamson, who coined the phrase "Washington Consensus", when trying to define the set of policy reforms that most Washington officials thought beneficial for Latin America countries in 1990. ${ }^{13}$

The earlier IMF analysis of economic problems focused on excessive government expenditure, over-valuation of currencies, quantitative controls over imports and negative real interest rates. The policies recommended cuts in government expenditure and getting prices right. The Washington Consensus added ten new elements, which could be summarized as: fiscal discipline; tax reform; interest rate liberalization; a competitive exchange rate; trade liberalization; liberalization of inflow of foreign direct investment; privatization; deregulation; secure property rights; and, lastly, a redirection of public expenditure priorities towards areas offering both high economic returns and a potential to improve income distribution, such as primary health care, primary education, and infrastructure.

Trade liberalization involved the removal of quantitative restrictions on imports, reduction in tariffs, the imposition of a uniform rate of tariffs, and free trade. In foreign investment, it prescribed non-discriminatory treatment between domestic and foreign enterprises. It further stipulated the return of nationalized enterprises to private hands, the closure of loss-making state enterprises, and a transfer of public firms to private hands. The domestic market deregulation agenda included the establishment of free markets for goods, labour and finance. In the 1990s, two new elements were added to secure political support for this package: the "imposition" of local government "ownership" of the programme; and introduction of "social safety nets".

The objective of structural reforms was to enhance the role of market forces, thereby strengthening the basis for strong and sustained growth. In the process, changes in the role of the State - through privatization and deregulation - and external liberalization were meant presumably to increase efficiency, and spur private sector activity in a growing number of successfully managed economies in all regions.

However, the Washington Consensus was marked by an ideological bias towards the positive role of liberalization in fine and the idea that market forces would respond quickly to pro-market structural adjustment programmes. Therefore, the Bretton Woods institutions tended to over-emphasize liberalization policies in the pursuit of structural adjustment programmes, disembedding them from a comprehensive development framework.

\footnotetext{
${ }^{13}$ Williamson, J. 2000. "What should the World Bank think about the Washington Consensus?", in
} The World Bank Research Observer, Vol.15, No. 2. 
The lack of an integrated approach in the Washington Consensus explains why the liberalization process, initiated in the 1980s, did not lead to deep economic structural transformation or the expected investment and supply impact, through market mechanisms. Indeed, one should give minimal credence to arguments involving various steps, such as that, stressed by the mainstream doctrine, of the virtuous circle regarding liberalization, structural adjustment and growth, since each of these linkages can easily break along the way - particularly when austerity and instability reduce output and market incentives directly, by-passing the resource reallocation upon which IMF programmes rely.

Finally, the Washington Consensus was also marked by talk about convergence. With the collapse of the Soviet bloc, the idea of a convergence (at the heart of the theories of modernization in the 1950s) returned through a neo-evangelistic discourse on the end of history and the victory of democratic capitalist systems over socialist systems. Once the "spectre of socialism" vanished, the Promised Land was open to any country which would implement the right policies, and follow the example of advanced capitalist countries. Fukuyama declared then, "We have become so accustomed by now to expect that the future will contain bad news with respect to the health and security of decent, democratic political practices that we have problems recognising good news when it comes. And yet the good news has come". ${ }^{14}$

Indeed, according to the mainstream rhetoric the way for a developing country to join the global economy and reap its rewards was to emulate the advanced economies, which all share certain key features (openness, private ownership, and corporate governance), and offer a relatively straightforward set of guideposts for the most fundamental reforms. ${ }^{15}$ All countries would be better able to develop their comparative advantages, enhance their long-term growth potential, and share in an increasingly prosperous world economy, if their policies were adapted to meet the requirements of the global economy. ${ }^{16}$ This is how they were to access "the limitless accumulation of wealth" and achieve "an increasing homogenization of all human societies". ${ }^{17}$

The early 1990s are marked by the symbolic violence of the Washington Consensus doctrine. Deviation from the new orthodoxy was viewed as a sign of either madness or backwardness, because of the failure of past alternative strategies - a perspective that largely acted to disarm criticism and undermine the development of any alternatives. ${ }^{18}$ Paul Sweezy remarks that:

\footnotetext{
${ }^{14}$ Fukuyama, F. 1992. The end of history and the last man. New York, Free Press, p.xiv.

${ }^{15}$ Sachs, J. 1995. “Consolidating capitalism”, in Foreign Policy, No. 98 (Spring), p. 3.

${ }^{16}$ IMF. 1997. World Economic Outlook, I - Global Economic Prospects and Policies, May, doc. internet, p. 4.

${ }^{17}$ Fukuyama, F. 1992, op. cit., p. xiv.

${ }^{18}$ Gill, S. 1995. "Theorizing the Interregnum: The Double Movement and Global Politics in the 1990s", in B., Hettne, ed., International Political Economy - Understanding Global Disorder, London, Zed Books, p. 66.
} 
In the conventional wisdom of the capitalist world, the economic globalization that has characterized the recent decade is considered to be a benign process that brings multiple benefits to those who have participated in it (the inhabitants of the capitalist countries, both those at the center and those in the periphery) and offers the promise of a better future to those who have so far remained outside (the people who left the capitalist orbit). ${ }^{19}$

The universal policy prescription from the Bretton Woods institutions was based on a revised version of the well-known theory of the "trickle-down" that would result from the activation of the following virtuous circle: liberalization leads to integration, which leads to economic growth, which leads to poverty reduction. Given the strong correlation between growth and poverty reduction, structural policy reforms were presumably designed to achieve efficiency and growth objectives, and also promote poverty reduction. ${ }^{20}$ The early 1990 s was a period of global utopia. The trend towards more integrated world markets was perceived as offering a huge potential for greater growth and presenting unparalleled opportunity for developing and post-communist countries to raise their living standards. ${ }^{21}$

In the 1980s and 1990s, the UN system was largely overshadowed by the Bretton Woods institutions, which took the lead in developing policy ideas and action programmes. It was subjected to increased pressure from some industrial countries to conform to the dominant orthodox ideas in its technical work and counsel. This undoubtedly had a dampening effect on the integrity and originality of work done by the UN agencies.

\section{The poor results of structural adjustment programmes}

The past two decades witnessed a wave of economic liberalization and privatization that swept the world. All categories of developing countries, as well as the transition economies, sought to overhaul their economic and social policies to varying degrees. But there is a growing realization that the new policies, even when fully implemented, did not fulfil their promise of rapid growth and poverty reduction. External liberalization, and particularly financial liberalization, have increased uncertainty and the potential impact of external shocks - as we have seen in East Asia with the domestic, social and economic cost of the international financial crisis of 1997.

\footnotetext{
${ }^{19}$ Sweezy, P. 1992. "Globalization - To what end? Part Two", in Monthly Review, Vol. 43, No. 10, p. 18.

${ }^{20}$ World Bank. 1993. Implementing the World Bank's strategy to reduce poverty. (Washington, D.C., World Bank, p.8.

${ }^{21}$ IMF. 1997. “Globalization's challenges for Africa”, in IMF Survey, Vol. 26, No. 11, p. 177.
} 
These policies shared a large part of the responsibility for the "lost decade" of the 1980s. They led to stagnation or decline in output, increase in unemployment, a drop in wages, reduction in public expenditure on social services, and an aggravation of poverty. ${ }^{22}$ Moreover, for several consecutive years, the heavily indebted middle-income countries experienced negative resource flows. For example, in Latin America and the Caribbean, GDP and per capita income fell by 6.6 and 16 per cent between 1980-88. The transfer of resources shifted from an inflow of nearly US $\$ 16$ billion in 1978-79 to an outflow of about US\$23 billion in 1987-88, equivalent to nearly 21 per cent of exports of goods and services. $^{23}$

In the $1980 \mathrm{~s}$, the international community offered structural adjustment as the answer. In the 1990s, integration through external liberalization was the new, and only, answer. Sharp contractions in demands, de-industrialization, the informalization of the economy and recurrent international financial crises had reinforced the problems and harmed the poorest, in many cases. In spite of continuing expansion in the developing countries as a whole, the sustained economic boom in the US, the situation of the least developed countries did not improve significantly, and in most cases economic growth failed to recover. By 2000, some 45 developing countries had per capita incomes below those of 10-25 years earlier, as did more than 20 transition countries. ${ }^{24}$ Not one developed country was in that position.

In the 1980s and 1990s, globalization was associated with declining growth rates as compared to previous eras. Of 89 countries, 77 per cent - more than three-quarters - saw their per capita rate of growth fall by at least 5 percentage points between the periods 1960-80 and 1980-2000. Only 14 countries - 13 per cent - saw their per capita rate of growth rise by that percentage from 1960-80 to 1980-2000. In Latin America, per capita GDP grew by 75 per cent in 1960-1980, whereas in 1980-98 it rose by only 6 per cent. For sub-Saharan Africa, per capita GDP grew by 35 per cent in the first period, but it has since fallen by 15 per cent. ${ }^{25}$ It is interesting to note that during the first period, import substitution industrialization policies brought unprecedented economic growth to scores of countries in Latin America, the Middle East, North Africa, and even to some in sub-Saharan Africa. Meanwhile, economic growth has been dramatically reduced in the 1980s and 1990s, despite a large increase in trade and a significant decline in tariffs in developing countries

Most Latin American, African and transition economies were caught in"low or negative growth equilibrium", with stagnant or declining living standards for the majority. It is now accepted by most specialists and development agencies that the pendulum had swung too far in one direction. In 1980-98, the median per capita income growth in developing countries was 0.0 per cent as compared to 2.5 per cent in 1960-79. This stagnation has

${ }^{22}$ Cornia, G. A., R. Jolly and F. Stewart (eds.), 1987, Adjustment With a Human Face (London: Oxford University Press).

${ }^{23}$ Dharam Ghai and Cynthia Hewitt de Alcantara, 1991, "The Crisis of the 1980s in Africa, Latin America and the Caribbean: An Overview", in Dharam Ghai (ed.), The IMF and the South (London: Zed Books).

${ }^{24}$ UNDP, 2002, Human Development Report 2002 (New York: UNDP), pp. 190-193.

${ }^{25}$ Weisbrot, M., R. Naiman, J. Kim. 2001. “The Emperor has no growth”, CEPR Briefing Paper, May 2001. 
been a disappointment for the pro-Washington Consensus movement. ${ }^{26}$ Moreover, the economic performance and social indicators of the least developed countries (LDCs) have lagged well behind those of other developing countries over the past two decades. Indeed, while the per capita GDP in LDCs in 1980 was 30.5 per cent of that in all developing countries, it had fallen to 22.8 per cent by 1998 .

The break-up of the communist political and socio-economic system and the building up of market systems, in many cases through the "shock therapy" supported by Bretton Woods institutions, was followed in practically all countries by drastic falls in production, employment and public social expenditure. Between 1989 and 1993, real GDP fell by 15 per cent in the five countries in Central Europe, by 32 per cent in South East European States, by 42 in the Baltic States and by 30 per cent in the ex-Soviet Union republics. By 1999, ten years into the transition, only the Central European countries had exceeded earlier GDP levels - and that by 9 per cent, a growth of less than 2 per cent per year. In the Commonwealth of Independent States (CIS), output levels were 55 per cent below those in 1989, in South-Eastern European transition economies by 30 per cent and in the Baltic States by 35 per cent. Total employment in the former communist countries was down by 15 to 20 per cent. Economic collapse had severe consequences for people: the number of people living in poverty rose more than tenfold between 1988 and 1994, from 14 to 119 million. The Federation of Russia accounted probably for the biggest failure of all, with a GDP decline of over 40 per cent, and an increase of its number of poor from 2 to 60 million by the mid-1990s. ${ }^{27}$

In some parts of the world, poor growth performance and rising problems of unemployment, job precariousness and social exclusion combined with a sharp increase of inequality in income distribution within countries. In an impressive review of 73 countries, accounting for 80 per cent of the world population and 91 per cent of the world GDP-PPP, Cornia shows that inequality within countries between the 1950s and the 1990s rose in 48 countries, and remained constant in only 16 countries. ${ }^{28}$ Only in nine countries is there evidence of a decline in income concentration over the period. He also argues that, if inequality declined between the 1950s and the 1970s, there was a reversal in inequality trends observed over the past two decades. Indeed, by the mid- to late $1990 \mathrm{~s}, 46$ of the 73 countries analysed had Gini coefficients higher than $0.35-0.40$ as opposed to 29 in the 1980s.

The lost decade of the 1980s and poor economic performance of most developing countries in the 1990s call for a critical reassessment of the purported growth-fostering and poverty-reduction effects of the liberalization policies advanced by IMF and the World Bank to legitimate their policy package. Recent economic literature shows that the growth impact of economic liberalization still remains to be demonstrated, and is somewhat a matter of controversy.

${ }^{26}$ Easterly, W. 2001. The lost decades: Developing countries' stagnation in spite of policy reform 1980-1998. World Bank Discussion Paper, Feb. 2001.

${ }^{27}$ Weisbrot, M., D. Baker, R. Naiman, G. Neta. 2001. "Growth may be good for the poor - But are IMF and World Bank Policies good for growth?”, CEPR Briefing paper, May 2001.

28 Cornia, G. 2001. Trends in income distribution in the post WWII period: Evidence and interpretation, paper presented at the UNU/WIDER conference on "Growth and Poverty", Helsinki, 25-26 May 2001, p. 19. 
Even if we accept the Dollar and Kraay thesis that growth is always good for the poor, because the income of the poor rises one-for-one with overall growth (it being very unlikely that income distribution would worsen so as to completely deprive the poor of growth benefits), one can argue that until now the Bretton Woods policy package has brought too little growth to many of the poorest countries, and fostered increasing inequalities within countries. ${ }^{29}$ Such an evolution implies, on the one hand, that the poor could not access the whole potential of any improvement in living conditions that would have been associated with a higher growth rate; and, on the other hand, that they also received a smaller share of the benefits of growth than they would have obtained with a better designed policy package that would have preserved or - better yet - improved income distribution.

Effective pro-poor growth cannot be based on the "trickle-down" assumption - not even when associated with capacity-building and empowerment measures to strengthen the chances of the poor to participate in growth and its benefits. Alternative structural adjustment policies are necessary, with a more favourable distributive impact on the poorest. Poverty reduction and income distribution are not exclusive, but must go hand in hand to make globalization work for all. Politics and inequality do matter: this is one of the most important lessons to be learnt from the past 20 years of structural adjustment. The other major lesson is that there is not always a trade-off between economic efficiency and social equity, but that they coexist in an area - combining a logic of accumulation and one of social justice - where each of them is strengthening the other and contributes to the emergence of a virtuous circle. Thus, what is needed is a growth policy that incorporates equity as a forethought rather than an afterthought, by shifting the ideological debate, so that the cost and limits of growth are viewed as critically as the costs and limits of redistribution. ${ }^{30}$

\section{The gap between rhetoric and reality}

The 1990s are characterized by a process of competitive liberalization and a massive rush of the developing countries for membership in the World Trade Organization (WTO). This spurred a trend towards free trade in a myriad of countries in all parts of the world, most with very different economic systems, at very different stages of development, and with very different prior development policy philosophies. As Dornbush argues, it entailed a radical shift of paradigm for most of the developing country governments: "In a broad swing of the pendulum, developing countries have been shifting from severe and destructive protection to free trade fever". ${ }^{31}$

Of the developing countries that ratified the Marrakech Agreement and joined the WTO, many did implement effective external liberalization policies. However, there is little escaping the fact that the economic opportunities of integration remain highly concentrated in the developed countries; a few developing countries are catching up, while the rest are

${ }^{29}$ Dollar, D., A. Kraay. 2000. "Growth is good for the poor", in Policy Research Working Paper, No. 2587, Washington, World Bank.

${ }^{30}$ Dagdeviren, H., R. van der Hoeven, J. Weeks. 2002. "Poverty reduction with growth and poverty", in Development and Change, Vol. 33, No. 3.

${ }^{31}$ Dornbush, R. 1992. "The case for trade liberalization", in The World Bank Economic Review, Vol. 6, No. 1, p. 69. 
falling further behind. Globalization is a game with winners and losers, but the rules of the game seem unfair to an increasing number of players. Most of them are evermore aware of this asymmetrical liberalization process, perceiving an uneven globalized economy that is heavily biased towards the interests of the transnational corporations and richest countries.

Thus, on one side, there is the mainstream rhetoric on the high potential of developing countries for greater growth and unparalleled opportunity to raise their living standards, associated with the trend towards more integrated world markets. ${ }^{32}$ Accordingly, these countries would benefit by opening up to international trade and capital, to the new technologies, managerial know-how, and financial capital needed to overcome the dismal economic legacy of the past 40 years. ${ }^{33}$ By joining the rest of the global economy, developing countries and transition economies would be able to import some prosperity from the rest of the world - so goes the theory.

On the other side, there is a growing awareness of the social problems inherent to the present process of globalization. As early as 1984, the State of the World's Children Report issued by the United Nations Children's Fund ((UNICEF) started calling for adjustment with a human face, building upon an earlier study, The Impact of World Recession on Children. ${ }^{34}$ Both studies provided evidence of the negative impact of stabilization and adjustment policies on growth, income distribution, incidence of poverty and on the well-being of children in a large number of countries. ${ }^{35}$ The study proposed alternative approaches with more expansionary macroeconomic policies; more selective and targeted taxation policies; government expenditure, foreign exchange and credit; improving the efficiency and equity of the social sector by restructuring public expenditure; compensatory programmes, such as public works employment schemes and targeted nutritional interventions; and monitoring of the well-being, living standards, health and nutrition of populations.

The project of the World Institute for Development Economics Research (WIDER) comprised 18 country studies: "[f]ocused on whether alternative policy packages could have been devised in particular country situations which would contribute to desirable adjustment and growth goals [...] at a lower social cost than incurred by the country packages that were in fact negotiated." ${ }^{36}$ The study concluded that there is no unified theory or policy that can facilitate solutions to problems of stabilization and adjustment. What seems to work well is an array of policies involving a combination of different approaches, according to the characteristics of the countries concerned. The WIDER study agreed with UNICEF findings on the negative social and growth effects of the orthodox policies. It emphasized the structural roots of poverty, was sceptical of the prominent role accorded to price mechanisms in promoting adjustment and growth, and suggested the need for more realistic macroeconomic and financial analysis based on institutional and real-life assumptions.

32 IMF. 1997. “Globalization's challenges for Africa”, in IMF Survey, Vol. 26, No.11, p. 177.

${ }^{33}$ Sachs, J. 1993. "Poland's jump into the market economy”, Cambridge: MIT Press, p. 3.

${ }^{34}$ UNICEF. 1984. State of the World's Children. London: Oxford University Press; UNICEF. 1983. The Impact of Recession on Children. New York: UNICEF.

${ }^{35}$ Cornia, G., R. Jolly, F. Stewart (eds.). 1987. Adjustment with A Human Face, London: Oxford University Press.

${ }^{36}$ Taylor, L. 1988. Varieties of Stabilization Experiences. London, Oxford University Press, p. 20. 
The need for more realistic policies was also underscored in a set of studies carried out under the auspices of the International Labour Organization (ILO), which looked into the impact of structural adjustment on the labour market. ${ }^{37}$ In commenting on the structural adjustment of the 1990s, an overview study concluded that the relation between that set of adjustment policies and the labour market was complex. ${ }^{38}$ Despite concerns for longer term issues such as growth, the actual programmes emphasized the short-term allocative functions of the labour market, such as abolishing minimum wages, revoking dismissal laws, not recognizing sectoral wage settlements, etc. Moreover, trade unions were seen as a hindrance to stabilization goals, an important leitmotiv of structural adjustment policies. The studies point out that many of these labour market instruments were put in place to improve allocative efficiency, and not to improve efficiency in building up human capital and social stability and achieving a greater sense of equity, while, later, these factors were more important for growth than achieving rapid stability. Thus by narrowly focusing on the allocative aspect of the labour market, the options for equitable and pro-poor growth development policies were seriously compromised under the Washington Consensus in the 1990 s. ${ }^{39}$

The studies of the United Nations Research Institute for Social Development (UNRISD) addressed issues such as the impact of crisis and adjustment on social structures and organizations, the struggles waged by different social groups to defend their economic interests; the effect of economic and social changes on the balance of political forces, on the nature and power of the State, as also on shifts in power between national and foreign economic and political interests. ${ }^{40}$ These studies showed that the implementation of stabilization and adjustment policies resulted in a weakening of popular institutions such as unions and cooperatives, the impoverishment of significant sections of the working and middle classes, a strengthening of the influence and power of foreign investors and creditors and of domestic groups linked to the international economy, and the decline of the power, reach and capacity of the State. A vital part of national decision-making on social and economic policies had been transferred, in actual fact, to foreign creditors, both private and official. The studies also analysed the survival strategies of vulnerable groups, and the links between the economic crisis and the intensification of ethnic and religious tensions, crime, violence and prostitution. ${ }^{41}$

Thus, many other developing countries have been "getting the raw end of the stick" in the 1980 s and the 1990s without seeing the carrot, despite substantial structural reforms to integrate the global economy and follow the Bretton Woods institutions' prescriptions. For these, few of the promised opportunities have opened up, even after they liberalized their

\footnotetext{
${ }^{37}$ See special section of The Journal of Development Studies on Structural Adjustment and the Labour Market, Vol. 36, No. 4.

${ }^{38}$ See R. van der Hoeven, L. Taylor. 2000. "Structural adjustment, labour markets and employment: Some considerations for sensible people", in Journal of Development Studies, Vol. 36, No. 4.

39 van der Hoeven, R. 2001. "Labour markets and economic reform under the Washington Consensus", in The Indian Journal of Labour Economics, Vol. 44, No. 3.

${ }^{40}$ Ghai, D. (ed.). 1991. The IMF and the South: The Social Impact of Crisis and Adjustment, London, Zed Books; Martinez, J., A. Diaz. 1996. Chile: the Great Transformation. Washington, D.C., Brookings Institution.

41 For more information on the Washington Consensus, see the first volume in this series, L. Emmerij, R. and T. G. Weiss. 2001. Ahead of the Curve: UN Ideas and Global Challenges, Bloomington, Indiana University Press.
} 
economies. Little, if any, new foreign direct investment has flowed in; capital has flowed out as a consequence of financial liberalization, and often enormous instabilities have arisen. The long-persisting problems of debt, low export earnings and scarcity of resources of all kinds seem only to have worsened, severely holding back the resumption of growth, even in the countries which are acknowledged to have been running their economies in accordance with the dictates of the IMF and the international community. To these, including many of the poorest countries, globalization seems a dream full of false promises, if not a nightmare of deceit.

We are facing a contradictory process in most poor countries of simultaneous inclusion (in the realm of the imagination) and marginalization (in day-to-day material terms) that must be highlighted when considering the social dimension of globalization. Rather than eliminating or attenuating differences and inequalities, the integration of national economies into a global system has on the contrary made those differences and inequalities more apparent, and in many ways more unacceptable. ${ }^{42}$ In such conditions, a globalization devoid of a vision of human global governance will be increasingly challenged, as more people experience its costs, and recognize that these are not due to minor or temporary disturbances affecting a small minority, but are part of an open-ended and long-term challenge to quality of life of the majority. ${ }^{43}$

\section{Towards a new generation of structural adjustment policies}

Over the years, the World Bank and IMF have gone astray on crucial issues - as most recently in the case of its market fundamentalism ideology of structural adjustment programmes that led to an excessive pressure on external liberalization and freeing capital markets. These mistakes have not occurred for lack of expertise or technical excellency. Rather, they reflect the way in which the interests and positions of the richer developed countries, mediated through various voting structures, have biased and blinkered much of the work of the Bretton Woods institutions. The WTO, though having a more democratic voting system, will suffer somewhat from the same weakness, because of the overwhelming bargaining power of the industrial countries.

Up to now, structural adjustment programmes focused mainly on economic liberalization, and not on the sustainability of their reform package, implemented through high conditionality mechanisms. Therefore, not only do structural adjustment programmes have to be implemented most of the time in very difficult conditions of macroeconomic and political instability, but they tend to aggravate the situation. The key issue according to Rodrik is that, "illiberal policies which do not damage the overall stability of the economic system are preferable to liberal policies which are inherently unsustainable or engender instability". ${ }^{44}$ This means that structural adjustment should be designed in such a way as to

${ }^{42}$ ILO. 1994. Defending values, promoting change - Social justice in a global economy: An ILO agenda, Geneva, ILO, p.18.

${ }^{43}$ Bienefeld, M. 1995. "Capitalism and the Nation State in the dog days of the twentieth century", in R. Millband and L. Panitch, eds., The Socialist Register - 1994, Merlin Press, p. 103.

44 Rodrik, D. 1990. "How should structural adjustment programs be designed?", in World Development, Vol. 18, No. 7, p. 934. 
strengthen a sustainable policy environment, rather than threaten policy stability. From this perspective, any progress in liberalization may be conditional to that meta-constraint of sustainability.

An explicit recognition of this fact in the design process of structural adjustment programmes would be a step forward towards a sustainable path to structural adjustment. The orthodox view of liberalization as the main policy tool for growth should be reconsidered cautiously by policy-makers, in the light of the past 20 years of experience of pro-liberalization structural adjustment programmes, which restored sustained growth in too few cases, and seem to have hindered growth in many other cases. At their best meaning those few cases - IMF and World Bank packages generated modest improvements in economic growth. At their worst, they were associated with riots, political instability, increasing income inequality and slower growth, despite even rising capital inflows. At the opposite end of the spectrum, the success stories of China (Taiwan) and the Republic of Korea show how effective developmental States, which control the integration process through industrial and trade policy, can be.

Since the main objective of the Bretton Woods institutions is to promote growth and macroeconomic stability, they should revise their policy priorities and give priority to policy sustainability and gradualism in policy implementation. Promoting sustainable human development in the age of globalization will require a very different set of priorities, objectives and policies from those implied by market fundamentalism. In the late 1990s, efforts were made to evolve more balanced approaches, which emphasize a stronger role for the State, as well as more vigorous policies to tackle unemployment and poverty.

Indeed, increasing impoverishment and deprivation raised serious doubts about the effectiveness of neo-liberal policies in promoting broad-based growth. The 1990s responded with a mixture of backlash, adjustment and public relations. Some efforts were made to rein in the extremes of policy prescriptions of the 1980s and to strike a balance with the concerns and approaches that had dominated development policy in the preceding decades. A new focus on poverty-reduction policies, developed by the Bretton Woods institutions, and the recent emphasis on participation and ownership in the decision-making process characterize the new comprehensive development framework associated with the post-Washington Consensus era.

An important step towards this new development paradigm was taken by Joseph Stiglitz in his 1998 lecture at UNCTAD; ${ }^{45}$ Stiglitz was at the time Senior Vice-President and Chief Economist at the World Bank. He pointed out the failure of the Washington Consensus and the standard structural adjustment programmes that confused the means with the ends, and called for an alternative paradigm. Stiglitz' principles for the new development strategy were based on the conclusions of World Bank research on the criteria of success and the viability of projects supported by the World Bank; ${ }^{46}$ its main conclusion was that

\footnotetext{
${ }^{45}$ Stiglitz, J. 1998. "Towards a new paradigm for development", $9^{\text {th }}$ Raul Prebisch Lecture, Geneva: UNCTAD.

${ }^{46}$ World Bank. 1995. Structural and sectoral adjustment - World Bank experience 1980-92, World Bank Operations Evaluation Study, Washington, D.C., World Bank; World Bank. 1998. Assessing aid: What works, what doesn't, and why, World Bank Operations Evaluation Study, Washington, D.C., World Bank; Isham, J., D. Narayan, L. Pritchett, 1995, "Does participation improve performance? Establishing causality with subjective data", in World Bank Economic Review, Vol. 9, No.2.
} 
participation and ownership are essential to successful change. Indeed, any attempt to impose change from the outside is very likely to engender resistance or a lack of commitment from local actors that will negatively affect the results of the initiative for change. Therefore, by establishing participatory mechanisms and involving the organizations of civil society representing people, it will be possible to strengthen ownership, reduce resistance to change, and facilitate consensus building.

The Poverty Reduction Strategy Papers (PRSPs) initiative, introduced in 1999 by the IMF and the World Bank, reflect both the inadequate progress in poverty reduction over recent decades in low-income countries, and the growing disappointment of the donor community over the way aid and debt relief have been delivered. The PRSP principles extend and largely incorporate the ideas developed by Stiglitz and by the World Bank within its Comprehensive Development Framework. The failure of conventional structural adjustment programmes is blamed mostly both on the lack of ownership of the programmes by countries implementing them, and, a lack of participation in policy-making.

The PRSPs can be seen as a device to ensure growing recognition of the importance of a poverty reduction strategy in the policy-making process of poor countries, and to help ensure the proper use of debt relief under the Enhanced Highly Indebted Poor Countries Facility. From this standpoint, a new conditionality is needed from the Bretton Woods institutions to give them access to their resources. All countries receiving the Highly Indebted Poor Countries debt relief and all countries for which the IMF Poverty Reduction Grant Facility is in place or is planned need to become committed to the Poverty Reduction Strategy initiative.

The key elements of the PRSPs are the following:

- it is a country-led strategy process. A PRSP is a government document which must be drafted by the national authorities of the country concerned;

- the timeframe for preparation are set by the country;

- it is grounded in a comprehensive understanding of poverty and its determinants;

- it is results- or outcome-oriented, with a special focus on policy impact on the poorest;

- it must be the result of a nationwide participatory process, which involves not only the various parts of government, but also civil society and the public; and

- the poverty reduction strategy must be based on a medium- to long-term approach, which implies careful consideration of sequencing, performance criteria and monitoring arrangements. 
Despite many critical views of PRSPs, the first evaluations seem to show that they did make a difference in designing structural adjustment programmes in poor countries. They achieved useful mainstreaming of poverty-reduction policies in national policy processes, and reoriented policy priorities towards the satisfaction of the needs of the poor. ${ }^{47}$ They also contributed to the creation of a new space for domestic policy dialogue, and stimulated new public-private partnerships and participation. By integrating NGOs and civil society organizations in national policy processes, the PRSPs played an important role in increasing their capacities and strengthening their voices. This evolution was not entirely unproblematic, and the consultation has been very often unsatisfactory to a lesser or greater degree according to the countries. The more militant NGOs or trade unions have in many cases been excluded from the participatory process. More generally, civil society organizations have been only lightly involved in the policy-making process, and, most often, PRSPs have been associated with consultation rather than real participatory mechanisms which would have enabled NGOs and trade unions to influence policy.

What is more of concern is the conclusion that PRSPs do not constitute a major change from the past as regards core structural adjustment policies. Indeed, PRSPs are based on the mainstream doctrine that openness to international trade and liberalization is good for growth, which is itself good for the poor. ${ }^{48}$ The potential for global integration to reduce poverty is well illustrated in the new rhetoric by the cases of Brazil, China, India, Hungary or Viet Nam, which are experiencing higher growth and beginning to catch up. Hence, structural adjustment programmes remain dominated by the objective of growth, and the poverty reduction strategy is based on an updated version of the good old "trickle-down" hypothesis.

There is no alternative but to maintain macroeconomic stability, provide a conducive investment environment (especially for FDI) and support policy regimes which are open to trade. Yet in the meantime, some pro-poor measures must be taken - such as access to credit, training, small business services or social safety nets - to encourage the participation of the poor in growth and increase their ability to benefit from growth. The World Development Report, Attacking Poverty, published in 2000 by the World Bank illustrates the paradox of the new development paradigm. ${ }^{49}$ On the one hand, the World Bank proposes a innovative strategy for attacking poverty in three ways: promoting opportunity; facilitating empowerment; and enhancing security. Yet on the other, the World Bank excludes any alternative road to poverty reduction and human development, other than the core policies to stimulate growth and market forces, such as encouraging effective private investment, liberalization, a sound business environment and expanding into international markets.

${ }^{47}$ Booth, D. 2003. "Introduction and overview", in Development Policy Review, Vol. 21, No. 2, p. 131.

48 World Bank. 2002. Globalization, growth and poverty, Washington, D.C., World Bank; Dollar, D., A. Kraay. 2001. "Trade Growth and Poverty", paper presented at the WIDER Conference on Economic growth and poverty reduction, Helsinki, 25-26 May 2001.

${ }^{49}$ World Bank. 2000. Attacking Poverty. Washington, D.C., World Bank, pp. 7-8. 
As we can see, the scope for inputs of civil society organizations into policy-making processes is very limited. They are asked to own a policy framework which is mostly defined by national participatory mechanisms. Indeed, this is set out by the integration standards supported by the Bretton Woods institutions and the WTO. Participation is promoted within PRSPs so long as it does not conflict with the meta-constraint of integration into the global economy, and that the poor do not try to redefine the set of priorities radically.

The problem is that adequately addressing poverty issues would mean replacing growth and integration objectives in an integrated development strategy, based on the satisfaction of the material and immaterial basic needs of the poor, rather than on growth and integration criteria. Once again, it is matter of social dialogue and consensus building on the means and ends of development. Thus, PRSPs raise the question of the meaning of participation, its nature and role in the development process.

\section{Social conflicts and development: Some lessons for policy-making}

Development is not a gradual and harmonious process, but rather a disruptive and uncertain one.$^{50}$ It challenges the established regulations and hierarchy. At the heart of any development process, there is a complex mix of constraint and consent. To be successful, it is crucial to overcome the hostility or the indifference of the various actors involved. Participatory processes in democratic regimes ensure that concerns regarding the risks of change are not only heard, but also addressed. This is why these processes dissipate much of the resistance to change. Participation is thus essential to making systemic change more acceptable.

When individuals have a voice in shaping changes and activating recuperation mechanisms, they are more likely to accept or even embrace them. But "voice" always involves the decision to stick with the democratic system, to play the game. It is related to the expectation that society can be motioned again in the right direction after going astray through democratic practices. The "voice" option is an attempt to change the situation, rather than to escape from it. It relates to a model of justice, just as fairness.

As Bowles and Gintis argued:

[m]ore equal societies may be capable of supporting levels of co-operation and trust unavailable in more economically divided societies. Both co-operation and trust are essential to economic performance, particularly where limited or asymmetric information make both state intervention and market allocations inefficient. ${ }^{51}$

${ }^{50}$ See Lapeyre, F., 2002, "Le rêve d'un développement sans conflit", in Les Nouveaux Cahiers de L'IUED (PUF), No. 13.

${ }^{51}$ Bowles, S., H. Gintis. 1995. "Escaping the efficiency-equity trade-off: productivity-enhancing asset redistributions", in G. Epstein and H. Gintis, eds., Macroeconomic policy after the conservative era, Cambridge, Cambridge University Press, p. 411. 
This is one of the key factors explaining why, in historical retrospect, the era of the welfare state of social democracy was also the golden age of capitalism. ${ }^{52}$

Indeed, competitiveness, systemic transition and development always imply the mobilization of forms of social creativity that cannot be stimulated in a context of social fragmentation; the foremost problem of the twenty-first century is that of strengthening social ties. To be successful and transform society, structural adjustment programmes for integration need to convince individuals to participate. However, this will only take place if stakeholders do not prefer to be cautious and wait, or exit. Constraint is not enough. The transition and development process requires the mobilization and cooperation of these actors, their willingness to invest their time and resources, to be innovative, to solve problems, and make sacrifices. But this ownership and participation process should take place ex ante, long before the validation of the initiative and its benefits in terms of well-being. ${ }^{53}$ It means that the actors have to make a gamble, and place their trust in a project they consider fair.

One of the main lessons of the collapse of the bureaucratic socialist systems in the East is that bureaucratic initiatives to transform society - i.e. the history of intrasystemic reforms - have systematically met with the "exit" option of the population. It is the lack of ownership of reforms and people's lack of willingness to play the game that have led to the failure of most initiatives. One can say that this crucial problem has also affected IMF staff members when on mission to impose outside structural adjustment programmes through conditionality mechanisms.

The normal behaviour of a non-altruist actor when he/she decides to play a cooperative game (for example, to commit to systemic reform or to a development project) is to ponder the trust that can be placed on both the initiative (its credibility) and the initiative taker (its ability to achieve its objectives). Actors will play the cooperative game only if they think that the rules of the game are fair, and that the project has a great probability to succeed and reach its objectives. In other words, if agents trust it, and expect that the community will benefit from investment in this collective initiative. ${ }^{54}$ This kind of initial bet, that marks an actor's willingness to cooperate, creates social ties which are essential for ownership and the success of the initiative. In other words, development requires the emergence of a global cooperative strategy linking social actors with different and sometime antagonist demands that require institutional innovations able to produce "institutional compromises". One example was the case in the developed countries with the Fordist regime of accumulation in the 1960 s, based on fair sharing of productivity gains between profits and wages.

From this point of view, the loss of social cohesion and growth of micro-conflicts that may result from unfair globalization are a major threat to the new conditions of accumulation. The processes of exclusion and social fragmentation have weakened the social consensus on the objective of integration in the global economy, and thus the definition of a global cooperative development initiative seems more unlikely. The IMF is aware of the lack of a stable social foundation for the neo-liberal transition road. In its words:

\footnotetext{
${ }^{52}$ Bowles, S. and H. Gintis, 1995, op. cit., p. 409.

${ }^{53}$ See Reynaud, J.D. 1997. Les règles du jeu, Paris, Armand Colin.

${ }^{54}$ Favereau, O. 1995. "Conventions et régulation”, in R. Boyer et Y. Saillard, eds., Théories de la régulation : l'état des savoirs, Paris, La Découverte.
} 
The challenge therefore is how to minimise the tensions between globalization and the pressures for socialisation of risk. If such tensions go unaddressed, the danger is that the domestic consensus in favour of open markets will ultimately erode and trigger a generalised resurgence of protectionism. ${ }^{55}$

\section{From goals to reality: The long march of domestic and global reforms}

In this concluding part, we turn to the future. What lessons can be drawn from the record of past structural adjustment policies, that can help improve their contribution to sustainable development in the years ahead? What are the new issues, where should the focus be, what policies and actions are needed to maximize their impact on the living and working conditions of the poorest? What can be done to the global architecture to facilitate their implementation? What matters in policy-making is not whether you globalize, but how you globalize. The global economy is a source of opportunity in terms of profits, economic growth and better living conditions, but also one of disruption, instability and growing inequalities. Structural adjustment should be designed to promote a global integration that would improve the well-being of populations, and especially of the poorest.

\subsection{The Millennium Development Goals and structural adjustment}

In 2000, the UN Secretary-General presented his Millennium report, Vision for the New Millennium: We the Peoples: The role of the United Nations in the 21 st Century. ${ }^{56}$ It set out the challenges of improving international governance in the emerging global world economy. The report identified some basic priorities, such as sustainable growth, employment generation, and building structures for global equity and greater solidarity.

The Millennium Development Goals and working towards their fulfilment define a priority policy agenda for the UN and the international community. There is a need to investigate success story countries where rapid progress towards these goals has already been achieved or is underway, to explore cost-effective approaches and develop a low-cost system to monitor progress and ensure sustainable results. It is also necessary to analyse the links to the goals, especially in a manner which can be sustained. For example, if the goals are to be approached in ways which strengthen democratic empowerment at the local level, the political economy of the process also needs to be tracked and analysed.

\footnotetext{
${ }^{55}$ IMF. 1997. "Forces of Gobalization Must Be Embraced," in IMF Survey 26, No. 10, p. 154.

${ }^{56}$ Annan, K. 2000. Vision for the New Millennium: We the Peoples: the role of the United Nations in the $21^{\text {st }}$ Century, New York: United Nations.
} 
These Millennium Development Goals embody a remarkable coalition of international commitment and constitute a big step forward, as compared to anything the international community had agreed to previously. The goals are specific and time-bound; they focuse on the poorest people of the earth, and directly relate to the reduction of both poverty and social exclusion on a global scale. They define an immediate programme of action and country by country monitoring. Structural adjustment must be redesigned to move towards these human development goals, and the international system - including the UN, WTO, Bretton Woods institutions and donor countries - must work together, as never before, to provide support to individual countries in furtherance of that aim.

The international community urgently needs to address these goals. This will inevitably require a willingness to take on controversial and pioneering issues. Controversial, because many will not be popular with the major powers; and pioneering, because it must of needs look to the future if it is to succeed, and explore new possibilities and approaches. Goals for the reduction of poverty are important, but not enough; and without a substantial and sustained resumption of growth through pro-poor growth patterns, they will not succeed, especially in the case of the poorest and least developed countries. Nor do aid and debt relief, as on the present scale, suffice to ensure proactive development policy over the full range of countries concerned. It is nothing short of scandalous that the international dimension of the prolonged lack of growth in so many developing and transition countries has received so little attention. Instead, the failures of much of the developing world have been concealed by the promises of globalization.

Goals for poverty reduction, though of great importance, are only part of the agenda of development and structural changes. The UN will need to explore other issues, some closely related, others from the wider agenda of development, including issues that have long been a matter of UN and international debate. Some examples are: a macro-strategy for long-term sustainable development, social justice, and pro-job creation policies; a sectoral policy across the whole economy, including agriculture, industry and services; and self-reliance and a fairer international trade system, to ensure democratic control and transparency in the whole economy. Poverty reduction, though a priority, does not remove these and many other issues from the agenda of developing countries - especially the decent work issue. There is now widespread recognition that employment must be at the core of any development strategy, because employment gives people access to both income and social recognition. ${ }^{57}$ Such an employment-oriented strategy for development should be based on five pillars: 1) increasing incomes and productivity of the small farm sector; 2) stimulating the micro-enterprise sector; 3) expanding labour-intensive exports; 4) special employment-creation schemes, particularly through public infrastructure programmes; and 5) expanding social services to the majority of the population. ${ }^{58}$

\footnotetext{
${ }^{57}$ Sen, A. K. 1975. Employment, Technology and Development, London, Oxford University Press, p. 5.

${ }^{58}$ Ghai, D. 1999. "Some proposals for an employment strategy for human development, poverty eradication and environmental regeneration”, in Development, Vol. 42, No. 3, pp. 91-92.
} 
From this perspective, translating theory into practice is critical. It is one thing to launch an idea, it is quite another to translate it into concrete policies and projects. In this connection, many have criticized the problem of the "two World Banks". There is the World Bank of Presidential speeches, of the World Development Report, and of the abundant analyses produced by its research department, with many lofty ideas on poverty, income distribution, social capital, participation and the role of the State. But there is also the World Bank acting as the vector of mainstream doctrine. It is the World Bank of the bankers, of the interest of the major developed countries and of the people who make the loans and who do the actual negotiating with their counterparts in the developing countries. It is a very different world - often far removed from that of ideas and speeches.

\subsection{Globalization must work for all: The need for global governance}

One of the most important areas for the UN's future work and analysis concerns better and fairer management of the global economy. The 1990s also witnessed a heightening of concern with what are now called issues of "governance." The term refers to a variety of themes such as human rights, the rule of law, corruption, multi-party democracy, transparency, accountability, institutional development, and people's participation. The concern with good governance was triggered off by the end of the Cold War, and the explosion of ethnic, religious and regional conflicts in a large number of developing countries. The growth and strengthening of civil society institutions have also been an important contributory factor, along with increasing awareness that governance issues are crucial to economic and social progress.

The speed and pattern of globalization, the existence of massive inequalities and widespread poverty, the explosive growth of world civil society movements, the trends towards regionalization, the emphasis on democracy, participation and accountability these and other important developments have far-reaching implications for issues of global governance. No doubt, they will feature prominently on the international agenda in the coming years and decades. Indeed, governance issues are not confined to the national level: developing countries and civil society organizations have been demanding major reforms in global institutions and mechanisms for decision-making for decades.

In today's global economy, the international structure of governance, with their rules, norms, procedures and institutions are of ever-increasing importance for the functioning of the global economy. Growing levels of global inequality are in large part the result of these structures. These structures are man-made. Most are the result of national action and very unbalanced international negotiation. In both action and negotiation, the weakness of the poorest countries is only too apparent. Such countries are voiceless in shaping the new global architecture. They lack both bargaining power and expertise in analysing the implications of global proposals for their countries. By contrast, the rich developed countries often have hundreds of well-paid professionals, ready to be called upon to analyse the fine print of a clause in a trade dispute or a case arising in the global regulation of patent protection. 
These vast imbalances in wealth, power and professional capacity define one of the most important issues of reform in the area of development of poor countries. The UN has a key role to play in placing the needs and concerns of the poorest and the weakest countries and people on the international agenda. Here, the UN's record of the past half century yields important lessons, which can help the international community explore a number of crucial issues, essential to the better management of the global economy. Among such high-priority concerns:

- ensuring environmental sustainability on a global scale;

- global public goods, including new financial sources for their support;

- mechanisms to give more of a voice and fairer participation to poorer and weaker countries in global governance, including measures to offset their weakness in global negotiations;

- narrowing global economic gaps over the long term;

- exploring new issues of global justice;

- strengthening regional cooperation institutions;

- cancellation or reduction of official development assistance debt and debt service.

Domestic structural adjustment is crucial to good integration into the global economy, but without some deep restructuring of the international architecture to improve global governance, poor and weak countries will continue to be highly vulnerable and will never gain from globalization. In today's world, no country or community is an island unto itself. Progress in individual countries and communities is closely linked with progress in other countries and communities, and of the world as a whole. Global policy and action to expand choices and opportunities for people in all countries must include the poorest and weakest countries. 
A notable contribution in development policy was made by the series of Human Development Reports (HDRs) published annually by the UNDP since 1990. While in some respects these reports simply helped revive interest in the ideas associated with basic needs and employment-oriented approaches to development, they also helped advance thinking on development issues. The human development approach developed by Amartya Sen led to a novel framework for integrating different development concerns and objectives, and provided a fresh theoretical foundation for many familiar development objectives and policies. ${ }^{59}$ Broadening choices and strengthening human capabilities became new priorities, which climbed to the top of the policy agenda.

Since the goal of development is the improvement of the well-being of mankind, structural adjustment programmes should be designed as a tool to achieve this goal. New criteria of ex post and ex ante evaluation of structural adjustment policies should be established in line with the new development paradigm. Do the policies provide opportunities for all the population? Do they strengthen the capabilities of all, or have some groups been marginalized? How has the position of women and children changed with the implementation of the policies, especially in relation to gender equality and the advancement of women (and girls) in society at large? Gender advancement and equity become part and parcel of development - as stated in the Universal Declaration, and elaborated in the Convention for the Elimination of all Forms of Discrimination Against Women. ${ }^{60}$

Sen's great contribution was to have broadened the scope of development policy, which should give all citizens the means to achieve effective freedom to act by empowering them and by increasing their capabilities. In Sen's approach, capability and the freedom to act go hand in hand; ${ }^{61}$ what matters is not only the amount of income and goods each individual disposes of, but also what he or she can do with it. Individuals can have a job and a minimum standard of living, but may be denied professional mobility and be excluded from the life of the community or opportunities of social mobility because of ethnic or gender discrimination. Thus, entitlement to a few commodities is a necessary, but not sufficient, condition to enlarge an individual's set of choices; individual ability to convert goods into capability can differ a great deal. ${ }^{62}$ Instead of dealing only with shortage of income, development policy should also deal with what people can achieve with the

59 For further elaboration of these ideas, see Amartya Sen, Development As Freedom, Oxford University Press, Oxford, 1999; Amartya Sen, 1985, Commodities and Capabilities, Amsterdam, North Holland); A. Sen. 1987. On Ethics and Economics, Oxford, Blackwell.

${ }^{60}$ According to Sen's analysis, women frequently exhibit "adaptive preferences", preferences that have adjusted to second-class status. A reference to human rights provides an objective standard against which to consider whether a person's choices are being systematically constrained by social pressures and tradition.

${ }^{61}$ Sen, A. 1992. Inequality re-examined. Oxford, Clarendon Press.

${ }^{62}$ Sen, A. 2000. "Social Exclusion: Concept, Application and Scrutiny", in Social Development Papers no.1, Manila, Asian Development Bank. 
resources in their possession. In other words, everyone should have the freedom of choice to live the life they value. It is a much broader approach than the pro-poor growth or basic needs approaches.

Until now, structural adjustment programmes have been based on the virtuous relationship between liberalization, growth and poverty. While growth may be good for the poor from an income perspective and pro-poor growth solve their poverty problem, it does not overcome social exclusion. This is the crucial difference between "freedom from want" and "freedom to act". Therefore, the aim of a development strategy cannot be to provide compensation to those who are poor and excluded - but to build a more inclusive society. If not, it would only aim at managing outsiders in a fragmented society, and would limit itself to being an instrument of social control.

New economic and social policy to fight social exclusion must increase individuals' capabilities and empower them - rather than compensate the marginalized for the consequences of exclusion, and expect hypothetical "trickle-down" effects from growth to solve social problems. The main objective is to increase citizens' future prospects through a capability-enhancing policy approach, that is intended to develop freedom of choice. This involves the eradication of poverty and social exclusion and the fulfilment of basic needs and the core social rights of all. It requires that governments apply active economic, social and environmental policies, and promote and protect all human rights and fundamental freedoms on the basis of democratic and widely participatory institutions. Structural adjustment programmes should contribute to such a process, rather than limit it as they did in the 1980s and 1990s.

This is not to ignore that development is a process of economic growth and structural change. But this definition focuses on the significance of growth and structural change for people. Unless we know how people have been affected by growth and structural change, and how these changes have affected people's capabilities to make choices - we do not have the information required to assess whether or not the process should be counted as a progress. An expansion of human freedoms thus becomes the goal of development, and involves a revolution in the way structural adjustment policies are designed.

\section{Conclusion}

From the beginning, the UN has been centrally concerned with global development issues - what could be called "building an enabling framework on a global scale". In terms of human development, this involves concern for international action to ensure the opportunities that allow countries and individuals to develop their capacities and to exercise their human capabilities in three ways:

1. economic, social and cultural frameworks, national and international, which are dynamic and responsive to human needs and concerns, and in which individuals are free to exercise their capabilities; 
2. democratic and legal frameworks, within which elected governments can operate and flourish, practising inclusive democracy, with separation of powers and the rule of law; participation of civil society and public-private partnerships; national and international structures which ensure justice and accountability;

3. political and social stability in a peaceful and sustainable environment, avoiding extreme and unsustainable levels of inequalities.

This list of elements required for an enabling international and national framework of individual capabilities is far from exhaustive, and there are overlapping items in the categories. But it does provide a checklist against which to assess the focus and range of UN concerns in the promotion and support of development.

From this perspective, structural adjustment policies should be characterized by the following features:

- Country-based, rather than universal policies. They must refer to developmental priorities that have emerged from a domestic democratic process, which is crucial to ownership and participation of the population for the success of such policies. They should be based on what people consider the essential elements of a decent life which will depend on local, cultural and time-based criteria. Integration into the global economy is not an end but a means to increase the well-being of the population in relation to the standards of their society. The process of integration must be regulated to achieve this goal.

- A dynamic approach to economic efficiency and social justice, emphasizing the mutually reinforcing effect of equity and efficiency in the long term, in an appropriate institutional framework established to promote a global cooperative development strategy.

- A multidimensional policy framework, in which economic issues are not isolated from the social sphere, but are part of an integrated strategy to improve the living and working conditions of the population.

- A human development oriented, rather than growth-oriented, approach, based on empowerment and the strengthening of the freedom to act of the poor. Growth can be an important means of human development, if associated with redistributive, labour-intensive, and basic needs oriented policies. But it can also be very disruptive when the process of accumulation escapes social regulation frameworks, and leads to social fragmentation, polarization, and exclusion.

- A balanced global-local approach of development issues. The past 20 years have been marked by emphasis on internal factors rather than external factors to explain the poor economic and social performance of developing countries and transition economies. But we need to question the global economic social dynamics which are responsible for the current imbalances and growing inequalities in the world. There is a structural lack of opportunity and a situation of disempowerment for people trapped in the 
process of social exclusion, and it must be acknowledged. It is important to re-emphasize the link between the poor and the rich, and the excluded and the included, in the global economy.

- More emphasis on the creation of decent work. Unemployment and job precariousness are key factors explaining the process by which individuals or groups are wholly or partially excluded from full participation in society. Indeed, the strength of the links between the employment situation and other dimensions of economic and social life (family, income, living conditions and social contacts) suggests that people in precarious employment - whether they are unemployed or in a precarious job - greatly risk social exclusion. Unemployment and precarious forms of work are factors underlying social exclusion. Employment, especially a decent job for the household head, is considered the safest barrier against poverty and social exclusion.

- An emphasis on qualitative issues. Indeed, what is important in the analysis of social exclusion is not only the problem of the access to basic rights (employment, housing, health or education), but also the quality of such work, housing, health services or education. This is an important point to stress in the present phase of privatization which is affecting the quality of the services delivered to the poorest.

- The integration of the Braudelian idea of the "longue durée"(the long-term) into the analysis of economic and social transformation. There is no magic set of policies or best practices that are able to solve all of the development problems in a short period of time; continuity and flexibility are essential in an integrated development policy. Structural adjustment policies must be designed in a long-term perspective.

To conclude, we quote Reginald Green who argued at the Economic Commission for Africa's Conference on the Human Dimension of Africa's Recovery and Development in 1988:

Therefore, one basic test of all stabilization and structural adjustment programmes is whether they will improve the human condition [...]. If a programme cannot pass that test in prospect or in operation, it is fatally flawed and itself in need of structural adjustment or total design". ${ }^{63}$

This is the challenge of our new century. As we have seen above, a big step forward has already been taken by identifying the core policy elements of such a human development strategy.

${ }^{63}$ Green, R. 1990. "The human dimension as the test and a means of achieving Africa's recovery and development in Africa", in A. Adedeji, S. Rasheed and M. Morisson, eds., The human dimension of Africa's persistent economic crisis, London, Hans Zell, p. 3. 


\section{Bibliography}

Annan, K. 2000. Vision for the New Millennium: We the Peoples: the role of the United Nations in the $21^{\text {st }}$ Century. New York, United Nations.

Baker III, J. 1986. "Endettement et changement structurel”, Travail et Société, 3.

Balassa, B. 1968. Economic Growth, Trade and Balance of Payments in Developing Countries 196065. Washington, D.C, World Bank.

— . 1976. Export incentives and export performance in developing countries, ECLA / IBRD seminar on export promotion, Santiago, Chile, 5-7 Nov., p. 308.

Bhagwati, J. and A. Krueger. 1978. Foreign Trade Regimes and Economic Development: Liberalization Attempts and Consequences. Cambridge, Ballinger.

Bienefeld, M. 1995. "Capitalism and the Nation State in the dog days of the twentieth century", in R. Millband and L. Panitch, eds, The Socialist Register - 1994. New York, Monthly Review Press.

Booth, D. 2003. "Introduction and overview”, in Development Policy Review, 21(2).

Bowles, S. and H. Gintis. 1995. "Escaping the efficiency-equity trade-off: productivity-enhancing asset redistributions", in G. Epstein and H. Gintis, eds., Macroeconomic policy after the conservative era. Cambridge, Cambridge University Press.

Braudel, F., E. Labrousse. 1982. Ere industrielle et la société d'aujourd'hui. Siècle 1800-1950. Troisième volume. Années 1950 à nos jours. Paris, Presses Universitaires de France.

Colander, D. 1984. Neo-classical Political Economy. Cambridge, Ballinger.

Cornia, G. A., R. Jolly and F. Stewart (eds.). 1987, Adjustment With a Human Face. London, Oxford University Press.

Cornia, G. 2001. Trends in income distribution in the post-World War II period: Evidence and interpretation, paper presented at the UNU/WIDER conference on "Growth and Poverty", Helsinki, 25-26 May 2001.

Dagdeviren, H. R. van der Hoeven and J. Weeks. 2002, "Poverty reduction with growth and poverty", in Development and Change, 33(3).

Dollar, D. and A. Kraay. 2000. "Growth is good for the poor", in Policy Research Working Paper, No. 2587. Washington D.C., World Bank.

— . 2001. "Trade Growth and Poverty", paper presented at the WIDER conference on Economic growth and poverty reduction, Helsinki, 25-26 May 2001.

Dornbush, R. 1992. "The case for trade liberalization", The World Bank Economic Review, 6(1).

Easterly, W. 2001. “The lost decades: Developing countries' stagnation in spite of policy reform 19801998”, World Bank Discussion Paper, February 2001. 
Emmerij, L., R. Jolly, and T. G. Weiss. 2001. Ahead of the Curve? UN Ideas and Global Challenges. Bloomington, Indiana University Press.

Epstein, G. and H. Gintis. 1995. "Economic policies for sustainable growth", in G. Epstein and H. Gintis, eds., Macroeconomic policy after the conservative era. Cambridge, Cambridge University Press.

Favereau, O. 1995. "Conventions et régulation", in R. Boyer and Y. Saillard, eds., Théories de la régulation: l'état des savoirs. Paris, La Découverte.

Fukuyama, F. 1992. The end of history and the last man. New York, Free Press.

Ghai, D. (ed.). 1991. The IMF and the South: The Social Impact of Crisis and Adjustment. London: Zed Books.

— - and C. Hewitt de Alcantara. 1991. "The Crisis of the 1980s in Africa, Latin America and the Caribbean: An Overview”, in Dharam Ghai (ed.), The IMF and the South. London, Zed Books.

— . 1999. "Some proposals for an employment strategy for human development, poverty eradication and environmental regeneration", in Development, 42(3).

Gill, S. 1995. "Theorizing the Interregnum: The Double Movement and Global Politics in the 1990s “, in B. Hettne, ed., International Political Economy - Understanding Global Disorder. London, Zed Books.

Green, R. 1990. "The human dimension as the test and a means of achieving Africa's recovery and development in Africa" in A. Adedeji, S. Rasheed and M. Morisson, eds., The human dimension of Africa's persistent economic crisis. London, Hans Zell.

Held, D. 1995. Democracy and the global order. Cambridge, Polity Press.

Helleiner, G. 2001. "Markets, Politics and Globalization: can the global economy be civilised?", in Journal of Human Development, 2(1).

Hirst, P. “The global economy - myths and realities”, in International Affairs, 73(3).

ILO. 1994. Defending values, promoting change - Social justice in a global economy: An ILO agenda. Geneva, ILO.

IMF. 1997. "Forces of Gobalization Must Be Embraced”, in IMF Survey 26(10).

—. 1997a. "Globalization's challenges for Africa", in IMF Survey, 26(11).

—. 1997b. "World Economic Outlook, I - Global Economic Prospects and Policies", May. Washington D.C., IMF.

Isham, J., D. Narayan and L. Pritchett. 1995. "Does participation improve performance? Establishing causality with subjective data", in World Bank Economic Review, 9(2).

Jolly, R., L. Emmerij, D. Ghai, F. Lapeyre. Forthcoming, The UN contributions to development thinking and practices. Bloomington, Indiana University Press.

Journal of Development Studies. Special section on Structural Adjustment and the Labour Market, $36(4)$.

Krueger, A. 1974. "The political economy of rent seeking society”, in American Economic Review, 64. 
—. 1990. "Economists' changing perceptions of government", in Weltwirstschaftliches Archiv, 126(3).

Lal, D. 1994. Against Dirigism. San Francisco, ICS Press.

Lapeyre, F. 2002. "Le rêve d'un développement sans conflit", in Les Nouveaux Cahiers de l'IUED (PUF), 13.

Little, I., T. Scitovsky, M. Scott. 1970. Industry and Trade in Some Developing Countries. London, Oxford University Press.

Martinez, J., A. Diaz. 1996. Chile: the Great Transformation. Washington D.C., Brookings Institution.

Reynaud, J.D. 1997. Les règles du jeu, Paris, Armand Colin.

Rodrik, D. 1990. "How should structural adjustment programs be designed?", in World Development, 18(7).

Sachs, J. 1993. Poland's jump to the market economy. Cambridge, MIT Press.

— . 1995. "Consolidating capitalism", in Foreign Policy, 98.

Sen, A.K. 1975. Employment, Technology and Development. London, Oxford University Press.

—. 1992. Inequality re-examined, Oxford, Clarendon Press.

—. 1985. Commodities and Capabilities. Amsterdam, North Holland.

—. 1987. On Ethics and Economics. Oxford, Blackwell.

- 2000. "Social Exclusion: Concept, Application and Scrutiny", in Social Development Papers, 1. Manila, Asian Development Bank.

Stiglitz, J. 1998. Towards a new paradigm for development. Raul Prebisch Lecture 9. Geneva, UNCTAD.

Sweezy, P. 1992. "Globalization - To what end? Part Two", in Monthly Review, 43(10).

Taylor, L. 1988. Varieties of Stabilization Experiences. London, Oxford University Press.

The Pearson Commission on International Development. 1970. Partners in Development, New York, Praeger.

UNDP. 2002. Human Development Report 2002, New York, UNDP.

UNICEF. 1983. The Impact of Recession on Children. New York, UNICEF.

—. 1984. State of the World's Children. London, Oxford University Press.

van der Hoeven, R., Taylor, L. 2000. "Structural Adjustment, labour markets and employment: Some considerations for sensible people", in Journal of Development Studies, 36(4).

van der Hoeven, R. 2001. "Labour markets and economic reform under the Washington Consensus", in The Indian Journal of Labour Economics, 44(3). 
Weisbrot, M, R. Naiman and J. Kim. 2001. "The Emperor has no growth", in CEPR Briefing Paper, May 2001.

Weisbrot, M., D. Baker, R. Naiman and G. Neta. 2001. "Growth may be good for the poor - But are IMF and World Bank Policies good for growth?”, in CEPR Briefing paper, May 2001.

Williamson, J. 2000. "What should the World Bank think about the Washington consensus", in The World Bank Research Observer, 15(2).

World Bank. 1993. Implementing the World Bank's strategy to reduce poverty. Washington D.C., World Bank.

—. 1995. Structural and sectoral adjustment - World Bank experience 1980-92, World Bank Operations Evaluation Study. Washington D.C., World Bank.

- 1998. Assessing aid: What works, what doesn't, and why, World Bank Operations Evaluation Study. Washington D.C., World Bank.

— . 2000. Attacking Poverty. Washington D.C., World Bank.

—. 2002. Globalization, growth and poverty. Washington D.C., World Bank. 


\section{Policy Integration Department Working Papers prepared for the World Commission on the Social Dimension of Globalization}

No. 16 International finance: Meeting the needs of people in developing countries, José Guilherme Almeida dos Reis

No. 17 The gender dimensions of globalisation of production, Stephanie Barrientos, Naila Kabeer and Naomi Hossain

No. 18 Social exclusion in the context of globalization, Jan Breman

No. 19 Gender and globalization: A macroeconomic perspective, Çağatay Nilüfer and Ertük Korkurt

No. 20 Globalization, social exclusion, and work: With special reference to informal employment and gender, Marilyn Carr and Martha Chen

No. 21 Resources for social development, Antony Clunies Ross

No. 22 Does the new international trade regime leave room for industrialization policies in the middle-income countries?, Alisa DiCaprio and Alice Amsden

No. 23 Social dimension of globalisation in Latin America: Lessons from Bolivia and Chile, Alvaro García Hurtado

No. 24 Globalization: Social impact and policy actions: A partly annotated bibliography, Bernhard Gunter and Rolph van der Hoeven

No. 25 The social dimension of global production systems, Susan Hayter

No. 26 Reforming global economic and social governance:

a critical review of recent programmatic thinking, Jeremy Heimans

No. 27 Corporate social responsibility: An issues paper, Michael Hopkins

No. 28 Upgrading in global value chains, John Humphrey

No. 29 Implications of globalization and economic restructuring for skills development in Sub-Sahara Africa, Richard K. Johanson

No. 30 The outcome and impact of the main international commissions on development issues, Frédéric Lapeyre

No. 31 Globalization and structural adjustment as a development tool, Frédéric Lapeyre

No. 32 Globalization and perceptions of social inequality, Malte Luebker

No. 33 The changing structure of trade linked to global production systems: what are the policy implications?, William Milberg

No. 34 Corporate social responsibility: An overview of principles and practice, Jill Murray

No. 35 Inclusive development strategy in an era of globalization, Ignacy Sachs

No. 36 Social consequences of the globalization of the media and communications sector: Some strategic considerations, Seán Ó. Siochrú

No. 37 Globalization, history and international migration - A view from Latin America, Andrés Solimano

No. 38 Towards a different kind of globalization, or how the anti-globalizers view the world, Gijsbert van Liemt 